\title{
INTENSITAS KOMUNIKASI KEPALA MADRASAH, GURU, DAN TENAGA KEPENDIDIKAN DALAM MENINGKATKAN MUTU PENDIDIKAN
}

\author{
Denantia Fema Hernandeni \\ Ibrahim Bafadal \\ Maisyaroh \\ denantiafema.512@gmail.com \\ Universitas Negeri Malang, Jl. Semarang No. 5 Malang 65145
}

\begin{abstract}
The intensity of communication is exchange of information within the specified time. Improving the quality of education ini educational institutions is closely related to the communication of various parties that support the implementation of activities ini the institutions. Each institutions must understand the indicators of quality improvement. This study is used qualitative approach. The design of the study used a one-case study. The purpose of this study is to discribe the intensity of communication at MIN 1 Malang to improve the quality of education. Data was collected by interview, observation, and documentation. Implementation of the communication process that occurrs as result of the strategy used, such as approaching, does not have the distance between fellow subordinates, responsible communication, communication relax, maximize activities, communicative and intensive motivation. Support and inhibition in the implementation of communication also affect the result of communication that occurred. The existence of good communication intensity, smoothly and communication with improved the quality of education.
\end{abstract}

Keywords: intensity of communication, the quality of education

\begin{abstract}
Abstrak: Intensitas komunikasi adalah pertukaran informasi dalam kurun waktu tertentu. Peningkatan mutu pendidikan di lembaga pendidikan juga erat kaitannya dengan komunikasi yang dilakukan dalam berbagai pihak yang mendukung terlaksananya kegiatan-kegiatan yang ada di lembaga. Setiap lembaga juga harus mengetahui indikator-indikator dalam peningkatan mutu. Penelitian ini dilakukan dengan menggunakan pendekatan kualitatif mengenai intensitas komunikasi yang terjadi. Rancangan penelitian menggunakan studi kasus tunggal di MIN 1 Kota Malang. Pengumpulan data melalui wawancara mendalam, observasi berperan serta dan dokumentasi ditemukan bahwa komunikasi yang dilakukan dengan cara komunikasi antarpersonal, komunikasi kelompok dan komunikasi masa. Pelaksanaan proses komunikasi yang terjadi juga tidak lepas dari strategi yang digunakan, seperti melakukan pendekatan, jangan ada jarak antara sesama pegawai, komunikasi yang dapat dipertanggungjawabkan, komunikasi yang dilakukan secara santai, memaksimalkan kegiatan yang ada, pemberian motivasi dan komunikatif dan intensif. Pendukung dan penghambatan dalam pelaksanaan komunikasi juga berpengaruh terhadap hasil komunikasi yang terjadi. Dengan adanya intensitas komunikasi yang baik, lancar dan komunikatif akan meningkatkan mutu pendidikan.
\end{abstract}

Kata kunci: intensitas komunikasi, mutu pendidikan

Mewujudkan pendidikan yang berkualitas dimulai dari adanya penyelenggaraan pendidikan yang bermutu di madrasah. Masyarakat sering mengatakan bahwa antara kualitas dan mutu itu tidak dapat dipisahkan, karena saling berkaitan satu sama lain. Dimana kualitas sangat erat hubungannya dengan pelayanan yang diberikan kepada seseorang, sama dengan mutu. Pada pengertian mutu sendiri juga 
tidak terlepas dari kualitas dari sesuatu baik itu yang baik dan buruk dari madrasah. Sesuai dengan pendapat Pius (1994:505) bahwa, "mutu merupakan baik buruknya sesuatu, kualitas, taraf atau derajat (kepandaian, kecerdasan)". Pengertian mutu yang dimaksud disini adalah bagaimana seorang guru mampu memberikan pemahaman dan kemampuannya terhadap interaksi dalam proses pembelajaran. Sumber Daya Manusia (SDM) yang merupakan faktor utama untuk menjadikan madrasah bermutu juga harus diperhatikan. Khususnya sumber daya manusia dari guru yang mengajar. Selain itu untuk peningkatan mutu pendidikan maka, madrasah harus mengetahui indikator dari madrasah yang bermutu. Menurut Sammons et al (1995) ada sebelas indikator mutu madrasah, yaitu: (1) Profesional leadership (Kepemimpinan yang profesional); (2) Shared vision and goals (Visi dan tujuan bersama); (3) A learning environment (Lingkungan belajar); (4) Concentration on teaching and learning (Konsentrasi belajar mengajar); (5) Purposeful teaching (Meningkatkan belajar); (6) High expectation (Harapan tinggi); (7) Positive reinforcement (Penguatan positif); (8) Monitoring progress (Memantau kemajuan); (9) Pupil right and responsibilities (Hak dan tanggungjawab murid); (10) Home-school partnership (Kemitraan di rumah-sekolah); dan (11) A learning organization (Organisasi belajar).

Adanya indikator mutu membuat untuk meningkatkan mutu dari MIN 1 Kota Malang yang di sesuaikan dengan tujuan dan target madrasah. Indikator mutu yang ada di MIN 1 Kota Malang tersebut dapat dicapai dengan adanya komunikasi yang terjalin. Kedudukan komunikasi sangat dominan didalam proses intruksional dan manajerial, karena peran komunikasi sangat berpengaruh secara langsung. Keberhasilan madrasah dalam menyelenggarakan pembelajaran di madrasah juga tidak lepas dari adanya komunikasi. Hal ini senada dengan pendapat Yusup (2014:19) bahwa: Komunikasi dalam pendidikan tidak perlu disebut sebarapa penting kedudukannya, yang jelas proses pendidikan memang sebagian besar hanya bisa dilakukan melalui adanya proses komunikasi dan serapan informasi secara instruksional, manajerial, dan proposional. Artinya, hampir tidak ada proses pendidikan tanpa melalui komunikasi dan informasi.

Menurut Zulkarnain \& Sumarsono (2011:59), yaitu "komunikasi berarti menyebarkan atau memberitahukan informasi kepada pihak lain guna mendapatkan pengertian yang sama". Komunikasi merupakan hal yang penting dalam kehidupan sehari-hari termasuk dalam menyelesaikan tugastugas dalam bekerja. Terdapat beberapa arah aliran komunikasi yang dapat dilakukan oleh seseorang. Adanya komunikasi yang terjadi dalam organisasi akan memberikan motivasi tersendiri bagi tenaga kependidikan. Kinerja madrasah yang baik didukung dengan adanya intensitas komunikasi yang baik juga. Komunikasi yang dilakukan madrasah untuk meningkatkan mutu pendidikan antara lain dengan cara: (1) penyampaian informasi tersebut akan dapat tersalurkan terlebih mengenai fungsi dan tugas pegawai; (2) untuk menjaga komunikasi yang baik, madrasah mengadakan kegiatan dharma wanita yang diikuti oleh pihak laki-laki, baik istri hadir maupun tidak. Dari kegiatan-kegiatan tersebut dapat meningkatkan komunikasi yang terjalin di madrasah. Secara rutin madrasah juga mengadakan KKG (Kelompok Kerja Guru), rapat dan diskusi; dan (3) Pada waktu pagi hari Kepala Madrasah melakukan briefing sebelum melakukan aktivitas seperti biasanya. Briefing pagi dilakukan 3-5 menit untuk menyampaikan informasi yang baru. Sekecil apapun informasi yang didapat harus disampaikan sesegara mungkin.

\section{METODE}

Pada penelitian ini, peneliti menggunakan metode kualitatif. Menurut Arifin (2012:140) yang menyatakan bahwa, "penelitian kualitatif adalah suatu proses penelitian yang dilakukan secara wajar dan natural sesuai kondisi objektif di lapangan tanpa adanya manipulasi, serta jenis data yang dikumpulkan terutama data kualitatif'. Oleh karena itu, peneliti menggunakan pendekatan kualitatif dimaksudkan untuk membuktikan kajian yang mendalam mengenai kejadian istimewa dan memaparkan secara lugas mengenai intensitas komunikasi yang terjadi di MIN 1 Malang dalam meningkatkan mutu pendidikan.

Jenis penelitian yang digunakan dalam penelitian ini adalah studi kasus tunggal. Menurut Ulfatin (2015: 64) "studi kasus tunggal umumnya hanya melibatkan satu lingkungan tertentu pada periode tertentu pula". Peneliti menggunakan studi kasus tunggal karena terfokus pada satu lembaga pendidikan yang dianggap memiliki keunikan tersendiri, dimana lokasi penelitian di MIN 1 Malang. Peneliti 
melakukan penelitian di MIN 1 Malang terletak di Jl. Bandung Nomor 7c, Penanggungan, Klojen, Kota Malang. Informan kunci dalam penelitian ini adalah Kepala Madrasah, guru yang diberikan tugas membimbingan olimpiade atau lomba-lomba, Kepala Tenaga Usaha dan tenaga kependidikan yang melayani masyarakat secara langsung. Pemilihan informan sesuai dengan klasifikasi yang telah dibuat dan disesuaikan dengan judul penelitian.

Teknik pengumpulan data dengan cara penelitian kualitatif yaitu dengan cara wawancara mendalam, observasi berperan serta dan dokumentasi. Pada wawancara mendalam menurut Ulfatin (2015:192) "peda penelitian ini, pertanyaan yang diajukan sangat bergantung pada pewawancara itu sendiri”. Sehingga, pada waktu melakukan wawancara, peneliti tidak menggunakan panduan pertanyaan seperti pada wawancara terstruktur. Teknik wawancara ini digunakan sebagai pedoman peneliti untuk mengetahui data-data yang lebih mendalam, dengan menggunakan wawancara tidak terstruktur. Hal ini memungkinkan informan untuk dapat mengungkap secara lebih dalam tentang dunianya yang sesuai dengan fokus penelitian. Observasi atau pengamatan dilakukan untuk melengkapi data selain data yang di dapat dari proses wawancara dan dokumentasi, data tersebut di peroleh secara langsung dari lapangan. Teknik observasi ini dilakukan peneliti untuk mengamati secara langsung proses dan cara komunikasi yang terjalin antara kepala sekolah, guru dan tenaga kependidikan dalam meningkatkan mutu pendidikan dan mengamati kondisi sekolah. Peneliti juga menggunakan teknik dokumetasi, untuk mendapatkan dan mengumpulkan dokumentasi yang dilakukan untuk mengambil peristiwa atau kejadian saat observasi berlangsung, seperti foto proses komunikasi yang terjadi di sekolah, foto proses pembelajaran dan foto kondisi madrasah. Sehingga dapat disimpulkan teknik dokumentasi digunakan untuk pengmpulan data baik berupa data tertulis maupun data tidak tertulis sesuai dengan objek yang diteliti.

Menuru Wiyono (2007:90) menyatakan "analisis data adalah kegiatan mengubah data hasil penelitian menjadi informasi yang dapat ditafsirkan dan digunakan untuk mengambil kesimpulan dalam sistem penelitian". Reduksi data merupakan kegiatan memilih temuan penelitian yang pokok dan sesuai dengan fokus penelitian, baik temuan penelitian yang diperoleh melalui observasi berperan serta, wawancara mendalam, maupun dokumentasi. Selanjutnya peneliti menyajikan hasil reduksi data dalam bentuk narasi singkat, bagan, tabel, ataupun flowchart yang dapat dipahami. Hal ini dilakukan agar hasil reduksi data lebih terorganisir yang mempermudah penelitian dalam memahami hasil temuan yang di dapat di lapangan. Jadi peneliti akan membuat bagan untuk memperinci data penelitian yang telah diperoleh. Langkah terakhir adalah peneliti melakukan verifikasi data dari data display yang telah dibuat informan. Selain itu, peneliti juga membandingkan hasil display data dengan smber data yang akurat (data observasi dan dokumentasi). Hal tersebut bertujuan agar peneliti mendapatkan informasi yang sesuai dengan fakta dilapangan dan dapat menjawab fokus penelitian. Setelah verifikasi data hasil kesimpulan yang diperoleh dapat berupa deskripsi atau gambar suatu objek ataupun fenomena yang sedang terjadi atau bahakan dalam bentuk flowchart.

\section{HASIL}

\section{Proses Komunikasi Kepala Madrasah, Guru dan Tenaga Kependidikan dalam Meningkatkan Mutu Pendidikan di MIN 1 Kota Malang}

Proses komunikasi yang dilakukan MIN 1 Kota Malang dengan menggunakan empat bentuk proses komunikasi: (1) komunikasi antarpersonal, yaitu proses kounikasi antarpersonal. Bentuk proses komunikasi antarpersonal yang dilakukan di MIN 1 Kota Malang ada beberapa kegiatan sedang dan akan dilakukan oleh madrasah. Kegiatan ini melibatkan seseorang dengan orang lain baik itu secara langsung maupun tidak langsung (melalui media komunikasi). Proses komunikasi seperti ini hampir setiap kali dilakukan dikarenakan dengan menggunakan media komunikasi maka semua akan terasa cepat, dan sering kali telepon yang ada di ruang-ruang tertentu, sehingga jika ada tamu yang mencari pegawai dapat disampaikan dengan cepat.

Pelayanan yang prima harus diberikan madrasah demi mendukung komunikasi yang baik antara pegawai satu sama lain dan juga dari pihak luar madrasah. Madrasah menerapkan bahwa jika 
meminjam barang kepada orang lain harus meminta ijin kepada pemilik barang. Selain itu, madrasah juga mengajarkan kepada peserta didik untuk melakukan ijin apabila ingin masuk dan keluar pada saat proses pembelajaran di kelas. Peserta didik juga diajarkan dan menerapkan komunikasi dengan cara memberikan salam jika bertemu dengan guru; (2) komunikasi kelompok, merupakan proses komunikasi yang dilakukan pada suatu kelompok tertentu. Komunikasi yang dibangun pada komunikasi kelompok juga haruslah berjalan dengan intensif, agar apa yang sudah direncanakan dapat tercapai dan sesuai target. Maka dari itu kepala madrasah sebagai manajer harus mengawasi guru dan tenaga kependidikan dalam melaksanakan Tugas Pokok dan Fungsi (Tupoksi) yang telah tertulis, sehingga semua berjalan dengan maksimal. Kegiatan briefing pagi juga dilakukan oleh kepala madrasah, memang tidak lama, namun ini akan membuat proses komunikasi yang intensif karena dilakukan setiap paginya dan kegiatan ini juga dapat menjadikan wadah berbagi informasi yang ada diluar madrasah.

Pada proses komunikasi dalam permasalahan yang ada di madrasah baik itu tentang pegawai maupun tentang peserta didik juga sesuai dengan struktur organisasi MIN 1 Kota Malang, karena dalam pemberian keputusan terkait dengan solusi yang akan dilakukan disesuaikan dengan urutan yang telah dibuat. Sesuai dengan penjelasan salah satu guru MIN 1 Kota Malang yang telah dijelaskan diatas. Semua keputusan sudah melalui urutan struktur organisasi dalam melakukan tindakan keputusan, jika permasalahan tersebut tidak ditemukan solusinya maka barulah melakukan tindakan selanjutnya; dan (3) komunikasi massa melibatkan banyak orang dalam pelaksanaan komunikasi. Komunikasi massa juga dilakukan pada kegiatan proses belajar mengajar di kelas. Hal ini karena pada proses pembelajaran juga melibatkan orangtua peserta didik dengan keahlian yang dimiliki masing-masing. Kegiatan proses pembelajaran yang melibatkan orangtua peserta didik ini biasanya disebut dengan parent involvement. Orangtua peserta didik juga terlibat dalam merancang dan melaksanakan bersama kegiatan pembelajaran dialam bebas di luar madrasah. Kegiatan studi banding sering dilakukan oleh MIN 1 Kota Malang yang dilakukan pada hari sabtu. Website madrasah berisi mengenai kegiatan-kegiatan yang ada di madrasah, baik itu sedang dan akan terjadi, bahkan juga ada kegiatan-kegiatan yang sudah terjadi. Hal ini dilakukan agar masyarakat mengetahui proses pendidikan yang terjadi di madrasah, sehingga jika ada kegiatankegiatan yang membutuhkan aspirasi dari pihak luar madrasah dapat dikomunikasikan dengan pihak madrasah.

\section{Strategi Komunikasi antara Kepala Madrasah, Guru dan Tenaga Kependidikan dalam Meningkatkan Mutu Pendidikan di MIN 1 Kota Malang}

Strategi komunikasi yang dilakukan MIN 1 Kota Malang diantaranya sebagai berikut: (1) komunikasi sebagai aksi atau komunikasi satu arah. Strategi komunikasi seperti ini biasanya terjadi dengan pemberian tindakan atau contoh yang sedang menjadi topik pembicaraan serta penyapaian pesan yang terjadi. Komunikasi seperti ini biasanya dilakukan oleh kepala madrasah yang berwenang dalam memberikan keputusan untuk peningkatan mutu pendidikan yang ada di madrasah. Salah tugas kepala madrasah merupakan fungsi kepala madrasah, yaitu fungsi controlling. Pemberian motivasi kepada peserta didik dibutuhkan juga pada saat peserta didik akan melakukan lomba yang diikuti, agar peserta didik tetap semangat dan dapat mencapai dan meraih prestasi yang diharapkan.

Adapun beberapa peraturan yang dibuat oleh kepala madrasah, namun lebih banyak lisan yang disampaikan dari pada tulisan, yang langsung maupun tidak langsung disampaikan; (2) komunikasi sebagai interaksi atau komunikasi dua arah. MIN 1 Kota Malang juga melakukan strategi komunikasi dengan dua arah, dimana pada strategi ini hanya melibatkan penerima dan menerima pesan yang disampaikan. Strategi komunikasi seperti ini biasanya dilakukan oleh kepala madrasah yang mana melakukan komunikasi dengan pihak komite sebagai pendukung terlaksananya program madrasah. Sikap keterbukaan itu pula membuat para pegawai nyaman untuk melakukan tugas dan kegiatan yang ada di Madrasah. Intensitas komunikasi yang baik juga terjalin akibat adanya kegiatan-kegiatan yang membentuk kepanitiaan dari pegawai di Madrasah; (3) komunikasi banyak arah atau komunikasi sebagai transaksi. Pelaksanaan strategi komunikasi banyak arah yang mana kedua belah pihak mempunyai ketergantungan dalam memberikan umpan balik pada saat melakukan komunikasi. Strategi komunikasi seperti ini pasti memiliki keuntungan yang diperoleh satu sama lainnya. Terutama pada saat penyampaian 
masalah yang terjadi di madrasah. Contoh permasalahan yang terkait dengan proses belajar mengajar, dalam berkomunikasi harus sesuai dengan prosedur yang sudah ada di MIN 1 Kota Malang. Strategi komunikasi yang dilakukan oleh MIN 1 Kota Malang juga tidak hanya dalam bentuk tatap muka, namun komunikasi dengan memanfaatkan media yang ada. Media membuat komunikasi semakin cepat dan dapat membantu berkomunikasi jarak jauh. Dengan memaksimalkan kegiatan-kegiatan yang ada dan didukung dengan adanya media komunikasi serta wadah untuk menyampaikan pendapat dengan komunikasi, seperti whatsapp dan Kelompok Kerja Guru (KKG) untuk mengembangkan visi dan misi madrasah serta menyampaikan permasalahan yang terjadi pada saat proses pembelajaran di madrasah, sehingga satu sama lain dapat lebih akrab dalam tujuan yang sama. Utamanya dengan adanya kegiatankegiatan tersebut membuat komunikasi yang terjalin antara pegawai satu sama lain dapat lebih intensif.

Pada strategi komunikasi yang dilakukan MIN 1 Kota Malang dengan komite madrasah dalam meningkatkan mutu pendidikan di madrasah, selain itu salah satu peran komite madrasah adalah menjadikan moderator antara MIN 1 Kota Malang baik itu dengan pemerintah dan masyarakat. Oleh karena itu, strategi komunikasi yang dilakukan madrasah dengan komite madrasah menghasilkan empat peran utama bagi komite madrasah. MIN 1 Kota Malang juga didukung oleh paguyuban orangtua peserta didik.

\section{Pendukung dalam Komunikasi Kepala Madrasah, Guru dan Tenaga Kependidikan dalam Meningkatkan Mutu Pendidikan di MIN 1 Kota Malang}

Faktor pendukung tersebut diantaranya adalah sebagai berikut: (1) media pengantar. Media komunikasi yang canggih yang digunakan untuk berkomunikasi yaitu media whatsapp dengan pembuatan grup di masing-masing bidang. Grup whatsapp tersebut yang telah dibuat ada tiga jenis, yaitu grup humas, guru dan pegawai. Media pengantar pesan komunikasi yang digunakan madrasah tidah hanya telepon saja, tetapi juga menggunakan website madrasah yang dibentuk oleh pihak humas. Website madrasah juga dilakukan pembaharuan setiap berkala. Hal ini dilakukan agar informasi yang terkait tentang MIN 1 Kota Malang dapat selalu dipantau oleh masyarakat luar dan menjadikan madrasah menjadi lebih berkembang sesuai dengan teknologi yang sedang maju. Untuk mendukung media yang ada digunakan dalam berkomunikasi untuk menyampaikan pesan, maka MIN 1 Kota Malang mempunyai sarana dan prasarana yang mendukung; (2) komunikator memiliki kredibilitas sedangkan komunikan memiliki pengetahuan yang luas. Faktor pendukung selanjutan terkait dengan keadaan atau kondisi yang dapat dipercaya dan dipertanggung jawabkan. Sebagai seorang komunikator dalam menyampaikan pesan harus dapat dipercayai dalam memberikan informasi dan bertanggung jawab akan apa yang disampaikan. Sesuai dengan tugas yang telah diberikan kepadanya. Sedangkan sebagai komunikan sebagai penerima pesan maka harus mempunyai pengetahuan yang lebih luas. Demi berkembangnya madrasah menjadi lebih baik, maka seluruh aspek yang ada di madrasah harus maju bersama. Selain itu, sesama anggota madrasah harus saling membantu jika salah satu diantaranya membutuhkan, tanpa harus diberi tahu. Pegawai resepsionis juga harus menjadi pendengar yang baik dan merupakan komunikan yang mempunyai informasi yang dapat menjadi penjelas pada masyarakat. Proses pembelajaran yang dilakukan oleh guru juga harus mempunyai tanggung jawab dalam melakukan tugasnya sebagai guru. Karena guru dan madrasah harus sejalan dalam meningkatkan mutu pendidikan. Penyelesaian pekerjaan harus sesuai dengan yang telah menjadi kewajiban masing-masing pegawai dan memberikan pendapat supaya madrasah lebih meningkat lagi dari segi mutu. MIN 1 Kota Malang selain memiliki budaya yang religius pada semua pegawai, juga memiliki budaya kerja yang perlu diterapkan dalam diri masing-masing pegawai; (3) keterampilan dalam mendengarkan dan memberikan umpan balik dalam berkomunikasi. Pada faktor pendukung komunikasi MIN 1 Kota Malang mempunyai komunikasi yang terampil dalam mendengarkan, karena faktor ini sangat berpengaruh dalam pelayanan yang diberikan. Hal ini dapat dilihat dari bagian front office yang ada di madrasah. Pegawai resepsionis selalu memberikan pelayanan prima dengan adanya rasa sungkan jika pelayanan yang diberikan tidak maksimal. Partisipasi paguyuban orangtua peserta didik juga merupakan pendukung yang ada di madrasah dalam mengembangkan mutu 
pendidikan. Antara pendukung madrasah dan lembaga pendidikan sendiri mempunyai komunikasi yang harus dijaga dan selalu memberikan respon atau umpan balik demi perbaikan madrasah, sehingga komunikasi yang terjalin bersifat positif dan sehat.

Komunikasi yang seperti ini harus selalu dibangun agar tidak terjadi kesalahan pahaman dalam melakukan persiapan dalam meningkatkan mutu pendidikan yang ada di madrasah, karena jika terjadi kesalahan dalam melakukan komunikasi akan menimbulkan permasalahan yang dapat mengganggu kelancaran kegiatan yang akan dilakukan selanjutnya.

\section{Penghambat dalam Komunikasi Kepala Madrasah, Guru dan Tenaga Kependidikan dalam Meningkatkan Mutu Pendidikan di MIN 1 Kota Malang}

Berikut beberapa penghambat pada proses komunikasi yang ada di madrasah: (1) hambatan dari proses komunikasi yang dilakukan. Hambatan ini terkait mengenai cara penyampaian pesan atau informasi yang dilakukan. Penghambat tersebut yang ada juga tidak hanya dapat mengganggu dalam proses pembelajaran yang sedang berlangsung di madrasah, tetapi juga dapat mengganggu dari kecepatan penyampaian informasi dari komunikan kepada komunikator. Penghambat yang ada juga dapat dijumpai dalam proses pembelajaran, dimana peserta didik ada tidur di kelas, sehingga hal ini dapat mengganggu penyampaian materi karena peserta didik yang lain memperhatikan peserta didik yang tertidur tersebut. Semua penghambat tersebut dapat ditangani oleh madrasah dengan cara kembali lagi dengan berkomunikasi secara baik satu sama lainnya. Penghambat yang berkenaan dengan media komunikasi.

Secara tidak sengaja peneliti pada waktu melakukan kunjungan ke madrasah pada saat itu juga ada permasalahan yang terjadi pada saluran telepon yang berada di ruang resepsionis. Kemudian beliau melaporkan permasalahan tersebut kepihak humas dan pihak humas langsung menelpon pihak Telkom untuk melakukan perbaikan. Hal ini merupakan salah satu wujud dari tindakan langsung dan cepat yang dilakukan MIN 1 Kota Malang dalam melakukan peningkatan mutu madrasah dalam hal pelayanan yang diberikan kepada masyarakat dan juga membantu pekerjaan dari pegawai resepsionis untuk menyampaikan informasi atau pesan kepada guru atau pegawai lainnya; (2) hambatan yang terkait dengan psikologi. Dalam berkomunikasi di MIN 1 Kota Malang, namun juga dari pihak komite yang mana setiap anggota komite madrasah mempunyai kesibukan sendiri-sendiri, sulit untuk hadir bersama-sama dalam forum atau diskusi. Solusi dalam hambatan tersebut dimana komunikasi yang terjalin jika berkenaan dengan komite madrasah dikomunikasikan saat ada kegiatan yang berlangsung di madrasah. Walaupun ada hambatan seperti itu, namun jika ada rapat yang berlangsung di madrasah tidak mempengaruhi jalannya rapat. Solusi yang dilakukan dengan mengkomunikasikan permasalahan tersebut pada saat kegiatan madrasah yang mana kepala madrasah selalu hadir pada saat kegiatan tersebut. Seperti saat briefing pagi yang selalu dilakukan oleh MIN 1 Kota Malang dan kemungkinan besar kepala madrasah hadir pada waktu itu.

Hambatan psikologi juga dirasakan pada pegawai junior. Terdapat pegawai yang belum lama berada di madrasah yang biasanya disebut sebagai pegawai junior, namun sudah diberikan tanggung jawab dan mempunyai jabatan yang lebih tinggi dari pada pegawai senior. Adanya permasalahan terkait dengan sikap yang ditunjukan tamu yang datang ke madrasah, dimana biasanya ada beberapa tamu yang bersikeras untuk mendapatkan informasi yang diinginkan pada hari itu juga. Hal ini membuat pegawai resepsionis harus mencari pengganti jika dirasa tamu yang bertanya belum percaya dan belum puas akan jawaban yang diberikan oleh pegawai resepsionis. Sampai tamu yang datang tersebut merasa puas akan jawaban yang diberikan dan semua pertanyaan terjawab dengan baik.

\section{PEMBAHASAN}

Berdirinya sebuah lembaga pendidikan yang sukses dan bermutu pasti akan memperhatikan komunikasi yang terjadi dalam sebuah lembaga pendidikan. MIN 1 Kota Malang merupakan lembaga pendidikan tingkat dasar yang berciri khas agama islam yang berada dibawah naungan Kementrian Agama Republik Indonesia. Baik buruknya kualitas pendidikan di madrasah bisa ditentukan oleh 
komunikasi yang terjalin yang ada di madrasah tersebut. Hal ini senada dengan pendapat Yusup (2014:19) bahwa, "komunikasi dalam pendidikan tidak perlu disebut sebarapa penting kedudukannya, yang jelas proses pendidikan memang sebagian besar hanya bisa dilakukan melalui adanya proses komunikasi dan serapan informas secara instruksional, manajerial, dan proposional. Artinya, hampir tidak ada proses pendidikan tanpa melalui komunikasi dan infromasi".

Komunikasi ini digunakan agar proses rencana kegiatan dapat dilakukan dengan lancar sesuai dengan tujuan dan target. Pelaksanaan yang ada di madrasah pastinya diperlukan adanya proses pendidikan yang mampu merubah mutu pendidikan yang ada agar menjadi meningkat. Proses pendidikan yang dilakukan tersebut menurut Nurhikmahyanti (2014: 268) dijelaskan bahwa, "proses merupakan berubahnya sesuatu menjadi sesuatu yang lain. Proses pendidikan dikatakan bermutu tinggi apabila mengkondisikan dan penyerasian serta pemanduan input sekolah (guru, siswa, kurikulum, uang dan peralatan) dilakukan secara harmonis, sehingga mampu menciptakan situasi pembelajaran yang menyenangkan, mampu mendorong motivasi dan minat belajar dan benar-benar mampu memberdayakan peserta didik".

Dari proses pendidikan dan komunikasi yang dilakukan juga, peneliti dapat mengetahui bentuk komunikasi yang dilakukan oleh MIN 1 Kota Malang dalam kesehariannya, baik itu yang bersifat formal dan non formal. Berikut penjelasan menurut Suranto (2010:13) dan hasil temuan yang didapat oleh peneliti: (1) komunikasi antarpersonal yakni komunikasi antara seseorang dengan orang lain, bisa berlangsung secara tatap muka maupun dengan bantuan media. Bentuk komunikasi antarpersonal ini sering digunakan dalam aktivitas dan kegiatan yang ada di MIN 1 Kota Malang. Biasanya jika ada urusan atau janji dengan tamu madrasah menyediakan alat komunikasi (telepon) untuk menghubungi yang bersangkutan, dengan memanfaatkan media komunikasi; (2) komunikasi kelompok, yaitu proses komunikasi yang berlangsung dalam suatu kelompok, contohnya diskusi kelompok, seminar, sidang kelompok dan sebagainya. Komunikasi kelompok ini juga sering sekali digunakan, karena setiap minggunya pasti MIN 1 Kota Malang melakukan komunikasi kelompok (diskusi kelompok, rapat). Rapat biasa dilakukan pada hari jumat, Kelompok Kerja Guru (KKG), dan briefing pagi yang dipimpin oleh kepala madrasah; dan (3) komunikasi massa, yaitu komunikasi yang melibatkan banyak orang. Pada bentuk komunikasi massa ini peneliti menemukan bahwa di MIN 1 Kota Malang menggunakan beberapa media komunikasi yang digunakan untuk berkomunikasi dengan masyarakat, komite madrasah, orangtua peserta didik dan antar pegawainya. Media yang digunakan telepon, website, whatsapp dan studi banding.

Komunikasi akan berjalan dengan baik dan efektif jika semua pihak mengetahui dan memahami komponen-komponen yang ada pada proses komunikasi. Komponen-komponen tersebut akan membantu berlangsungnya proses komunikasi yang akan dilakukan. Akan tetapi, untuk mencapai tujuan tersebut, strategi tidak berfungsi sebagai gambaran dalam penunjukkan arah saja, melainkan harus mampu menunjukkan bagaimana taktik operasional yang akan digunakan.

Guru di MIN 1 Kota Malang mempunyai komunikasi yang baik dengan peserta didik, hal ini terlihat pada saat proses pembelajaran, dimana pada saat guru menjelaskan materi harus mempunyai metode mengajar yang bervariasi, tidak hanya ceramah saja. Bahkan ada guru yang menerapkan bahwa yang menjelaskan materi terlebih dahulu adalah peserta didik dan guru menyimak, jadi antara guru dan peserta didik dapat saling memberikan masukan. Guru juga sering memberikan tugas secara kelompok kepada peserta didik dan melakukan diskusi agar interaksi yang terjalin bukan hanya antara guru dan peserta didik, melainkan peserta didik yang satu dengan peserta didik yang lain. Pembelajaran dalam startegi komunikasi yang dilakukan madrasah tersebut sesaui dengan strategi komunikasi yang dipaparkan oleh Asgarwijaya (2015:1016) ada tiga strategi komunikasi yang digunakan, berikut penjelasannya: (1) komunikasi sebagai aksi atau komunikasi satu arah. Komunikator berperan aktif dalam menjelaskan pesan sedangkan komunikan hanya mendengarkan; (2) komunikasi sebagai interaksi atau komunikasi dua arah. Antara komunikan dan komunikator keduanya dapat saling memberi dan menerima; dan (3) komunikasi banyak arah atau komunikasi sebagai transaksi.Komunikasi ini tidak hanya melibatkan interaksi antara komunikan dan komunikator yang lebih dari dua orang. 
Strategi komunikasi dalam pembangunan sebuah lembaga pendidikan sangat penting dalam perencanaan kegiatan yang dapat mendukung terciptanya mutu pendidikan yang diharapkan. Pelaksanaan komunikasi akan berjalan sesuai dengan tujuan dan target dari rencana yang dibuat oleh MIN 1 Kota Malang, jika komunikasi tersebut didukung dengan beberapa hal yang dapat mengakibatkan komunikasi tersebut berjalan dengan lancar. Pendukung dalam komunikasi ini dapat menghindarkan proses komunikasi dengan hal-hal yang dapat menghambat dalam komunikasi. Sehingga, dalam melakukan komunikasi madrasah dapat mempermudah dan berpengaruh positif dalam kegiatan komunikasi. Pelayanan yang diberikan merupakan hal yang perlu diperhatikan bagi MIN 1 Kota Malang, agar pelayanan yang baik dan juga budaya $5 \mathrm{~S}$ (Senyum, Sapa, Salam, Sopan dan Santun).

Semua pegawai yang ada di MIN 1 Kota Malang dapat membaur atau selalu bersama-sama dalam berkomunikasi pada saat ada waktu untuk sekedar melakukan komunikasi biasa. Pegawai mempunyai sikap pandai bergaul sehingga dapat berkomunikasi dengan nyaman antara satu sama lainnya. Hal tersebut dapat mendukung dalam penerimaan pesan dengan merespon pesan yang disampaikan dengan baik sesuai dengan apa yang disampaikan, tidak salah penafsiran atau salah paham. Penyampaian pesan seperti yang dilakukan oleh pegawai resepsionis dan juga cara komunikasi kepala madrasah, guru dan tenaga kependidikan di MIN 1 Kota Malang, sesuai dengan teori-teori faktor pendukung dari beberapa ahli, misalnya oleh Suranto serta Sofyandi \& Garniwa. Oleh Suranto (2010) dalam melakukan komunikasi faktor pendukungnya salah satunya bersikap ramah, pandai bergaul serta menerima dan mencerna pesan dengan baik, yang dijelakan sebagai berikut: (1) komunikator memiliki kredibilitas/ kewibawaan yang tinggi, dapat dipercaya, mampu memahami situasi di lingkungan kerja, memahami kondisi psikologis komunikan, bersikap supel, ramah, dan tegas, serta mampu menyesuaikan diri dengan masyarakat dimanai berbicara; (2) komunikan memiliki pengetahuan yang luas, memiliki kecerdasan menerima dan mencerna pesan, bersikap ramah, supel, dan pandai bergaul, memahami dengan siapa ia berbicara, bersikap bersahabat dengan komunikator.

Pegawai resepsionis juga harus mengetahui (peka) jika tamu yang diajak bicara kurang memahami apa yang dijelaskan. Selian itu, pada staf humas yang bertugas terkait kepegawaian dari MIN 1 Kota Malang, menjelaskan terkait dengan apa yang harus diperbaruhi dalam status kepegawaian misalnya, maka pegawai harus secara sesama menjelaskan yang mana setiap pegawai lainnya mempunyai daya pemahaman sendiri-sendiri, sehingga harus mendengar apa yang dirasa kurang memahami. Beberapa faktor pendukung tersebut dijelaskan Sofyandi \& Garniwa (2007:166), yaitu beberapa keterampilan yang juga perlu dimiliki dan dikembangkan bagi komunikasi yang efektif, yaitu: (1) keterampilan mendengarkan aktif. Mendengar dengan penuh perhatian, minat, penerimaan dan disertai keinginan untuk mengambil tanggung jawab dalam penyelesaian sesuatu; (2) keterampilan umpan balik, yang bersifat penghargaan atau pujian atas suatu prestasi yang bersifat positif, sedangkan umpan balik negatif adalah umpan balik yang bersifat kritikan atas prestasi yang tidak memuaskan. Biasanya, umpan balik positif yang sering ditanggapi dengan senang hati oleh penerimanya, sedangkan yang negatif tidak demikian halnya; dan (3) salian dari sudut pihak-pihak yang teribat.

Penghambat komunikasi yang terasa adalah mengenai media yang digunakan dalam komunikasi sendiri, dikarenakan media komunikasi sangat berperan dalam penyampaian pesan yang akan disampaikan oleh komunikator. Media komunikasi tersebut yang sering digunakan di MIN 1 Kota Malang adalah telepon, whatsapp dan website. Karena hambatan tersebut dapat membuat tamu yang sedang menunggu kecewa. Selian itu, jika hambatan media tersebut berlangsung lama, maka dapat membuat beliau juga kesulitan. Hambatan mekanis dan hambatan media yang diperoleh peneliti dari informan tersebut terdapat dipenjelasan menurut Fajar (dalam Nurdianti, 2014: 148). Yang mana hambatan-hambatan tersebut diuraikan sebagai berikut: (1) hambatan dari proses Komunikasi, yatu dari pengirim pesan, penyandian/symbol, media, dalam bahasa sandi dan penerima pesan; (2) hambatan psikologi, dari hambatan sosio-antro-psikologis, hambatan semantik, hambatan mekanis dan hambatan ekologis. 
Solusi yang dilakukan dari permasalahan tersebut salah satunya, pihak madrasah harus memperbaiki peralatan dan media komunikasi yang terganggu oleh pembangunan yang terjadi dan media komunikasi yang sedang rusak. Hambatan-hambatan yang terjadi dalam melakukan komunikasi yang ada di MIN 1 Kota Malang tidak hanya yang dijelaskan diatas, adapula hambatan-habatan lain yang peneliti temui. Hambatan tersebut berasal dari Sumber Daya Manusia (SDM) yang ada di MIN 1 Kota Malang. Terdapat pegawai yang merasakan ada faktor penghambat dari kesenioritasan yang ada di madrasah, hal ini dikarenakan banyak pegawai di madrasah yang senior.

Kondisi tersebut dapat berupa sikap, prilaku atau dari perasaan orang tersebut. Faktor penghambatan dari faktor sosio-antro-psikologi yang ada di MIN 1 Kota Malang sesuai dengan teori yang dikemukakan dari beberapa ahli dari faktor penghambatan dalam komunikasi, misalnya dari teori yang dikemukakan dari Effendy yang merupakan salah satu ahli yang mengungkapkan dari pengertian hambatan sosioantro-psikologis. Seperti yang dijelaskan Effendy (2015:11) ada 4 (empat) hambatan komunikasi, salah satunya mengenai hambatan sosio-antro-psikologis bahwa: (1) ambatan sosio-antro-psikologis, (2) hambatan semanti, (3) hambatan mekanis dan (4) hambatan ekologis.

\section{KESIMPULAN DAN SARAN}

\section{Kesimpulan}

Berdasarkan hasil temuan penelitian dan bahasan mengenai judul yang peneliti lakukan dapat disimpulkan tahapan pada media yang digunakan dalam komunikasi yang dilakukan oleh MIN 1 Kota Malang seperti media komunikasi telepon, whatsapp dan website. Bentuk proses komunikasi yang digunakan MIN 1 Kota Malang dalam proses komunikasi untuk meningkatkan mutu pendidikan adalah dengan komunikasi antarpersonal, komunikasi kelompok dan komunikasi massa.

Strategi komunikasi yang digunakan di MIN 1 Kota Malang ada dua pihak yang memerlukan strategi agar komunikasi yang terjalin dapat meningkatkan mutu pendidikan di madrasah, strategi-strategi yang digunakan MIN 1 Kota Malang dalam berkomunikasi dengan cara: (1) melakukan pendekatan; (2) jangan ada jarak antara sesama pegawai; (3) komunikasi yang dapat dipertanggungjawabkan; (4) komunikasi yang dilakukan secara santai; (5) memaksimalkan kegiatan yang ada; (6) pemberian motivasi; dan (7) komunikatif dan intensif. Faktor pendukung komunikasi yang intensif dilakukan oleh madrasah diantaranya adalah (1) fasilitas yang memadai; (2) adanya pemberian motivasi oleh kepala madrasah; (3) pemberian reward dan hukuman agar pegawai termotivasi untuk lebih berkembang; (4) pemberian pelayanan yang baik kepada pengunjung min 1 kota malang; (5) jika ada permasalahan dan informasi yang penting langsung ditanggapi oleh semua anggota madrasah; (6) komunikasi yang dilakukan secara santai; dan (7) pegawai yang memiliki rasa profesional, inovasi, integrasi, tanggungjawab, dan keteladanan. adapun kendala yang ditemukan pada saat komunikasi adalah (1) kesenioritasan; (2) pelayanan yang ada di resepsionis terkadang kewalahan menghadapi tamu yang memiliki argumen yang banyak; (3) Rusaknya fasiitas madrasah (telepon); (4) kesibukan dari anggota komite madrasah untuk melakukan pertemuan atau diskusi; dan (5) pesan yang disampaikan di grup whatsapp hanya di baca oleh beberapa anggota tertentu.

Solusi dari penghambat yang ditemukan tersebut sebagai berikut: (1) menata bahasa yang digunakan; (2) bersikap profesional; (3) pegawai memiliki kesabaran dan tlaten dalam menjelaskan; (4) jika ada masalah dalam hal fasilitas madrasah langsung ada tindakan perbaikan saat itu juga (memanggil petugas telkom); (5) kegiatan diskusi atau pertemuan tetap diadakan dan hasil dari diskusi tersebut diinformasikan melalui media komunikasi (grup) yang sudah dibentuk; dan (6) kepala madrasah langsung menegur dan memberikan pengertian jika diperlukan.

\section{Saran}

Penelitian ini memberikan saran kepada: (1) kementrian agama, dengan adanya kebijakan dan aturan yang telah dibuat tidak hanya membuat namun mengkoordinasikan secara langsung dengan lembaga pendidikan; (2) madrasah dan pendidikan agama, dengan adanya layanan dan bimbingan tidak hanya menampung aspirasi dari masyarakat namun harus berkomunikasi terjun langsung kelapangan; 
(3) kepala MIN 1 Kota Malang, dapat memberikan waktu yang lebih pada saat adanya permasalahan yang harus diselesaikan pada saat itu juga; (4) guru MIN 1 Kota Malang, lebih meningkatkan kinerja yang bagus seperti itu dapat meningkatkan nilai mutu pendidikan yang ada di madrasah menjadi lebih baik lagi; (5) tenaga kependidikan MIN 1 Kota Malang, menciptakan pelayanan yang prima agar semua dapat mendukung peningkatan mutu pendidikan di madrasah; (6) jurusan administrasi pendidikan, agar hasil penelitian ini dapat dijadikan sebagai salah satu referensi tema penelitian mahasiswa berikutnya yang terkait dengan komunikasi yang terjalin di madrasah dalam meningkatkan mutu pendidikan yang dilakukan disetiap lembaga pendidikan; dan (7) peneliti lain, dapat melanjutkan pada bagian yang belum terungkap secara menyeluruh pada kegiatan-kegiatan yang ada di madrasah.

\section{DAFTAR RUJUKAN}

Arifin, Z. 2012. Penelitian Pendidikan Metode Paradigma Baru. Bandung: PT Remaja Rosdakarya.

Asgarwijaya, D. 2015. Strategi Komunikasi Interpersonal Antara Guru Dan Murid Paud (Studi Deskriptif Komunikasi Interpersonal Antara Guru dan Murid PAUD Tunas Bahari Dalam Kegiatan Belajar Mengajar). E-proceeding of Management, 2(1): 1008-1027.

Effendy, O. U. 2015. Ilmu Komunikasi: Teori dan Praktik. Bandung: PT Remaja Rosdakarya.

Nurdianti, S. R. 2014. Analisis Faktor-Faktor Hambatan Komunikasi Dalam Sosialisasi Program Keluarga Berencana Pada Masyarakat Kebon Agungsamarinda. Jurnal Ilmu Komunikasi, 2(2), 145-159. Dari http:// ejournal.ilkom.fisip-unmul.ac.id.

Nurhikmahyanti. 2014. Pengelolaan Penjamin Mutu di Sekolah Menengah Atas. Jurnal Manajemen Pendidikan, 24(4): 267-273.

Pius A. P. \& Dahlan, M. 1994. Kamus Ilmiah Populer. Surabaya: Arkola.

Sammons, P.: Hillman, J.; Mortimore, P. 1995. Key Characteristics of Effective Schools: A Review of School Effectiveness Research. London: OFST.

Suranto, Aw. 2010. Komunikasi Sosial Budaya. Yogyakarta: Graha Ilmu.

Ulfatin, N. 2015. Metode Penelitian Kualitatif di Bidang Pendidikan. Malang: MNC Publishing.

Wiyono, B.B. 2007. Metode Penelitian: Pendekatan Kuantitatif, Kualitatif dan Action Research. (Burhanuddin, ED). Malang: Fakultas Ilmu Pendidikan Universitas Negeri Malang.

Yusup, P. M \& Rachmatika, R (Ed). 2014. Ilmu Informasi, Komunikasi, dan Kepustakaan (Volume 3). Jakarta: Bumi Aksara.

Zulkarnain, W. \& Sumarsono, R. B. 2011. Manajemen Perkantoran Pendidikan. Malang: Fakultas Ilmu Pendidikan Universitas Negeri Malang. 